\title{
EFFECT OF LINOLEIC ACID ADDITION ON THE CIS9-TRANS11- CONJUGATED LINOLEIC ACID CONTENT OF KEFIR
}

\author{
Betül Oskaybas Emlek, Ayşe Özbey* \\ Department of Food Engineering, Niğde Ömer Halisdemir University, Niğde, Turkey \\ Received /Geliş: 01.10.2020; Accepted / Kabul: 29.04.2021; Published online /Online bask1: 31.05.2021 \\ Oskaybas Emlek, B., Özbey, A. (2021). Effect of linoleic acid addition on the cis9-trans11-conjugated linoleic acid \\ content of kefir. GIDA (2021) 46 (4) 895-902 doi: 10.15237/gida.GD20115 \\ Oskaybas Emlek, B., Özbey, A. (2021). Linoleik asit ilavesinin kefirin cis9-trans11-konjüge linoleik asit \\ içeriğine etkisi. GIDA (2021) 46 (4) 895-902 doi: 10.15237/gida.GD20115

\begin{abstract}
Conjugated linoleic acid (CLA) and CLA isomers, present naturally in dairy and meat products, are the natural and functional components. Ruminal microorganisms, such as Butyrivibrio fibrosolvens, lactic acid bacteria (LAB), and propionibacteria can convert linoleic acid (LA) to CLA. In this study, the effect of different linoleic acid (LA) concentrations $(0,0.5,1,2 \%)$ and different storage time $(0,2,7,14$ and 21 days) on the CLA content of kefir was investigated. The highest CLA content was found on day 0 in the kefir sample to which $0.5 \% \mathrm{LA}$ was added but there is no significant difference between control and $0.5 \% \mathrm{LA}$. On the contrary, the lowest CLA content belonged to the sample including 2\% LA after 21 days of storage. The results suggested that certain amounts of LA could be used to enhance the functional properties of kefir.
\end{abstract}

Keywords: Conjugated linoleic acid, kefir, linoleic acid, functional food

\section{LİNOLEİK ASİT İLAVESINIIN KEFİRİN CIS9-TRANS11-KONJÜGE LİNOLEİK ASİT İÇERÍĞİNE ETKİSI}

\section{ÖZ}

Süt ve et ürünlerinde doğal olarak bulunan konjuge linoleik asit (KLA) ve KLA izomerleri, doğal ve fonksiyonel bileşenlerdir. Butyrivibrio fibrosolvens, laktik asit bakterileri (LAB) ve propionibacteria gibi ruminal mikroorganizmalar, linoleik asidi (LA) KLA'ya dönüştürebilmektedir. Bu çalşsmada, farklı linoleik asit (LA) konsantrasyonları (\%0, 0.5, 1 ve 2) ilavesinin ve farklı depolama sürelerinin $(0,2,7$, 14 ve 21 gün) kefirin KLA içeriği üzerine etkisi araştırılmıştır. En yüksek KLA içeriği \%0.5 LA ilave edilen 0. gün kefir örneğinde bulunmuştur ancak kontrol örnekleri ve \%0.5 LA ilave edilen kefir örnekleri arasında istatistiksel olarak önemli bir fark bulunmamıştır. Aksine, en düşük KLA içeriği 21 günlük depolamadan sonra \%2 LA içeren kefir örneğinde saptanmıştır. Sonuçlar, kefirin fonksiyonel özelliklerini geliştirmek için belirli miktarlarda LA kullanılabileceğini göstermiştir.

Anahtar kelimeler: Konjuge linoleik asit, kefir, linoleik asit, fonksiyonel gida

${ }^{*}$ Corresponding author / Yazışmalardan sorumlu yazar:

$\square$ : ayse.ozbey@gmail.com @: (+90) 3882254305

回: (+90) 3882250110

Betül Oskaybas Emlek; ORCID no: 0000-0002-0238-8948

Ayşe Özbey; ORCID no: 0000-0003-3210-4077 


\section{INTRODUCTION}

Kefir is a traditional, functional food that originated from the Caucasus and some countries of Eastern Europe (Domagała et al., 2009; Barukčić et al. 2017). It has been used to improve and maintain health for many years (Satir and Guzel-Seydim, 2016). Kefir is a fermented probiotic beverage containing yeast and some species of bacteria, including lactic acid bacteria (LAB) and acetic acid bacteria (Kim et al., 2016). Several studies have demonstrated kefir's useful effect on health, including anticarcinogenic properties, hypocholesterolemic effect, antibacterial activity, and improving the immune system (Barukčić et al., 2017; Gao et al., 2013; Zelovitiset al., 2016). Beneficial effects of kefir come from its bioactive components produced by yeast and bacteria (Gaware et al., 2011). The main microorganism species found in kefir grains are Lactobacillus plantarum, L. kefir, Lactococcus lactis subsp. lactis, Saccharomyces, and Acetobacter (Gamba et al., 2016). The fatty acid composition of dairy products can be changed through the activity of LAB (Vieira et al., 2015). During fermentation, some bacteria can convert fatty acid to specific fatty acids (do Espírito Santo et al., 2012), such as conjugated linoleic acid (CLA) in milk. Thus, the fatty acid composition including linoleic acid (18:2n6) (LA) may change due to the production of CLA (Abd El-Salam et al., 2010; Vieira et al., 2015). This conversion is a favorable situation because CLA has various beneficial effects on health, such as exhibiting anticarcinogenic activity (Kim and Liu, 2002) and preventing obesity and atherosclerosis (Van Nieuwenhove et al., 2007). In addition, CLA has an antioxidative effect and is able to reduce the level of low-density cholesterol (Lin, 2000).

CLA is a group of positional and geometric isomers of LA and has been frequently investigated in recent years (Csapó and VargaVisi, 2015). CLA is found naturally in meat and dairy products (Bhattacharya et al., 2006), as well as some bacteria that are able to generate it. Butyrivibrio fibrisolvens is a rumen anaerobic bacterium, which is the first proven species producing CLA (Kepler et al., 1966). CLA isomers are biohydrogenation intermediates of LA produced by $B$. fibrosolvens during conversion from linoleic and linolenic polyunsaturated fatty acid to stearic acid (Sébédio et al., 2003). Several studies have shown that $L$. acidophilus, $L$. delbrueckii subsp. bulgaricus, L. delbrueckii subsp. lactic, L-lactis subsp. cremoris, L. lactis subsp. lactis, and Streptococcus salivarius subsp. thermophilus are able to produce CLA (Xu et al., 2004).

Different methods have been proposed for enhancing the daily consumption of CLA; e.g., improving the substrate for CLA production or factors affecting bacteria growth, by adding vegetable oils or dietary fibers to food (Siurana and Calsamiglia, 2016; Whitlock et al., 2006). Farsad-Naeimi et al. (2015) demonstrated that addition of safflower oil to kefir increased the CLA amount of the samples. However, to the best of our knowledge, the effect of linoleic acid addition on the CLA content of kefir has not been investigated in the literature.

This study aimed to determine the CLA amount in kefir produced by adding of different amounts of LA and evaluate the effect of storage time on the CLA content. It is considered that this study contributes to the literature by filling a gap and providing useful data to improvement of functional foods.

\section{MATERIALS AND METHODS}

\section{Material}

Raw cow milk was purchased from Nigde (Turkey). Kefir grains (aerobic lactobacilli 8.4, anaerobic lactobacilli 8.3 , lactococci 9.1 , acetic acid bacteria 5.2, total yeast content $6.2 \log \mathrm{cfu} /$ $\mathrm{ml}$ ) were obtained from Nigde Ömer Halisdemir University. LA, 9c-11t CLA and 9t-11t CLA standard were purchased from Sigma-Aldrich Company Ltd. (St Louis, USA) and sodium methoxide $\left(\mathrm{CH}_{3} \mathrm{ONa}\right)$ was obtained from TCI (Tokyo Chemical Industry Co., Ltd., Singapore). Sulfuric acid $\left(\mathrm{H}_{2} \mathrm{SO}_{4}\right), \quad$ 2-propanol $\left(\mathrm{CH}_{3} \mathrm{CH}(\mathrm{OH}) \mathrm{CH}_{3}\right)$, isooctane $\left(\mathrm{CH}_{3} \mathrm{C}\left(\mathrm{CH}_{3}\right)_{2} \mathrm{CH}_{2} \mathrm{CH}\left(\mathrm{CH}_{3}\right) \mathrm{CH}_{3}\right)$, acetonitrile $\left(\mathrm{CH}_{3} \mathrm{CN}\right)$, and hexane $\left(\mathrm{C}_{6} \mathrm{H}_{14}\right)$ were purchased from Merck (Darmstadt, Germany). All solvents and chemicals were of reagent grade, except for hexane and acetonitrile, which were of HPLC grade. 


\section{Methods \\ Production of Kefir}

The first stage of kefir production was the activation of the grains. For this purpose, after storage under proper conditions, the grains were transferred into aseptically semi-skimmed $(1.5 \%$ milk fat) cow UHT milk supplied from local markets in Nigde. Then, the milk was incubated at $25 \pm 1{ }^{\circ} \mathrm{C}$ until the $\mathrm{pH}$ value decreased to 4.6, at which point the grains were separated from the milk. This process was repeated thrice.

At the second stage of kefir production, $0.5,1$ and $2 \% \mathrm{LA}$ was added to the raw cow milk, which was then pasteurized at $90^{\circ} \mathrm{C}$ for $10 \mathrm{~min}$ and cooled to $25^{\circ} \mathrm{C}$. The milk was inoculated with kefir grains $(2 \% \mathrm{w} / \mathrm{w})$ at $25^{\circ} \mathrm{C}$ in water bath. After the $\mathrm{pH}$ of samples was $4.6(\sim 24 \mathrm{~h})$, the kefir grains and kefir were separated through leaching and samples were taken for the first-day analysis $\left(\mathrm{t}_{0}\right)$. The remaining samples were stored in a screw-capped tube at $4{ }^{\circ} \mathrm{C}$ until analysis (for 2, 7, 14 and 21 days). In addition, a kefir sample without LA was produced to constitute the control.

\section{Preparation of Fatty Acid Methyl Esters}

Fatty acid methyl esters were formed by modifying the method described by GuzelSeydim et al. (2006). Approximately $0.5 \mathrm{~g}$ kefir samples were mixed with $1 \mathrm{ml} \mathrm{2-propanol} \mathrm{and} 1$ $\mathrm{ml}$ isooctane for $60 \mathrm{~s}$ in a capped glass tube. 100 $\mu \mathrm{l}$ was taken from the supernatant and dried in a vacuum oven (Vacucell - MMM Medcenter Einrichtungen, Germany). Then, $2 \mathrm{ml}$ of $\mathrm{NaOCH}_{3} / \mathrm{MeOH}(0.5 \mathrm{M})$ was added and mixed for $60 \mathrm{~s}$. The blended samples were kept at $50{ }^{\circ} \mathrm{C}$ for $10 \mathrm{~min}$ in water bath and cooled at ambient temperature for about $10 \mathrm{~min}$. The samples were interfused with $1.5 \mathrm{ml}$ of $\mathrm{H}_{2} \mathrm{SO}_{4}(1 \%)$ prepared in methanol for $60 \mathrm{~s}$. After adding $\mathrm{H}_{2} \mathrm{SO}_{4}$ into the samples and mixing them for $60 \mathrm{~s}$, they were maintained at $80^{\circ} \mathrm{C}$ for 10 minutes and cooled until reaching ambient temperature. Finally, the samples were extracted with $1 \mathrm{ml}$ of isooctane and $3.5 \mathrm{ml}$ of $\mathrm{K}_{2} \mathrm{CO}_{3}(6 \%)$.

\section{High Pressure Liquid Chromatographic Analysis}

The CLA analysis of the raw cow milk and kefir was carried out using HPLC (Shimadzu, Japan) equipped with two ChromSpher 5 Lipids analytical columns connected in series (each 4.6 $\mathrm{mm}$ i.d. $\times 250 \mathrm{~mm}$ stainless steel; $5 \mu \mathrm{m}$ particle size; Varian, California, USA). Besides, a UV detector operated at $233 \mathrm{~nm}$ was used. This method was suggested by Sehat et al. (1999). The sample amount was $20 \mu \mathrm{l}$. The mobile phase was hexane containing $0.1 \%$ acetonitrile, which was isocratic at a flow rate of $1.0 \mathrm{ml} / \mathrm{min}$. Chromatographic analysis was undertaken under the same conditions for all samples. $0.1-2 \mathrm{mg} / \mathrm{ml}$ of $9 t-11 t$ CLA standard was used for quantitative analysis.

Recoveries were determined in duplicate in milk using pure standards in the range $0.02-0.8 \mathrm{mg} / \mathrm{g}$ in esterification media prior to the analysis of samples with the HPLC procedure. The result was $100.00 \pm 1.247 \%$, suggesting that the procedure was reliable and appropriate for CLA analysis in kefir.

\section{Proximate Analyses}

The composition analysis of raw cow milk included the determination of dry matter, ash, fat, and protein. Determination of dry matter was performed by the drying method (AOAC Method 930.15), total protein analysis by the Kjeldahl method (AOAC Method 991.20), and fat content by the butyrometer method (AOAC Method 2000.18) (AOAC, 2005). The $\mathrm{pH}$ value of the samples was measured using a digital $\mathrm{pH}$-meter (VWR International Ltd., Dublin, Ireland).

\section{Statistical Analysis}

The experiments were carried out in duplicate (two repetitions, two parallels). The data of the experiments were subjected to an analysis of variance (ANOVA) using SPSS Statistics v. 17.0 (SPSS Inc., Chicago, IL, USA). The difference in the averages was assessed using Duncan's test. The values were expressed as means and standard deviations.

\section{RESULTS AND DISCUSSION}

According to the results, the raw milk showed the following characteristics: dry matter $11.99 \pm 0.156 \%$; fats $3.66 \pm 0.055 \%$; protein $3.12 \pm 0.044 \%$; ash $0.70 \pm 0.007 \%$, and the CLA 
content $0.725 \pm 0.019 \mathrm{mg} / \mathrm{g}$. The values obtained for the composition of cow's milk were similar to those reported by Vargas et al. (2008). Besides, the values for the CLA content of cow's milk were within the average range determined by Jiang et al. (1998). Furthermore, kefir production using cow's milk was found to enhance the CLA content. The values obtained for the CLA content of the control kefir samples were higher than the CLA content of cow milk.

LAB are commonly found in dairy products, such as kefir and yoghurt. Jiang et al. (1998) reported the use of some $\mathrm{LAB}$ as starter culture for dairy products and suggested that these bacteria were capable of producing CLA from LA. Many factors, such as the available concentration of LA, $\mathrm{pH}$ value in medium, temperature of incubation, and type of bacteria affect the yield of conversion from LA to CLA (Gorissen et al., 2015). In this study, we investigated the effect of LA addition to kefir on CLA production, and the results showed that the highest CLA content belonged to the kefir including $0.5 \%$ LA (Table 1) but it did not statistically significant $(P>0.05)$. However, when the LA content increased above $0.5 \%$, the CLA amount of kefir started to decrease. Previous research evaluating the effect of different concentrations of LA on CLA production by L.acidophilus reported that the greatest increase in CLA was found in the sample containing the lowest concentration of LA (Gorissen et al., 2015). In another study, when different concentrations of sunflower oil were added to skim milk, the highest CLA production was obtained from $L$. brevis at the lowest concentration while L. lactis had the lowest CLA content at the same concentration (Puniya et al., 2008). Li et al. (2012) evaluated the effect of different L. plantarum strains on CLA conversion by adding different concentrations of sunflower oil to the MRS broth. The authors observed similar results in that when the concentration of sunflower oil exceeded a certain amount in medium, conversion from LA to CLA decreased, indicating that free LA inhibited the conversion process promoted by LAB. However, the same effect was not observed until a certain level of LA, which may be associated with the antibacterial effect of CLA on some bacterial strains. Li et al. (2012) reported that the conversion capability of CLA varied according to microorganism. In another study Gorissen et al. (2015) reported that LA inhibited the $L$. reuteri strain, but did not observe any negative effect of CLA isomerism on $\mathrm{LAB}$. The authors also noted that in some cases, LA may have an inhibitory effect on the growth of LAB (Gorissen et al., 2015). In the current study, the increase in the LA of kefir to a certain level did not have a negative effect on CLA production. Jenkins and Courtney (2003) also reported that LA was more effective in the inhibition of LAB than CLA isomers. In another research, increasing the LA amount reduced the CLA levels, indicating the role of LA in decreasing the antibacterial effect (Lin et al., 1999). Lee et al. (2018) evaluated the fluctuation of CLA content in soybean powder hydrolysate milk and fermented soybean hydrolysate milk by adding different amounts of safflower oil to the samples and found that when the optimum supplemental concentration of safflower oil was exceeded, CLA conversion did not change significantly in the latter. Concerning soybean powder hydrolysate, in the current study, the CLA content was reduced up to a certain amount of LA. Therefore, we deduced that kefir containing $0.5 \%$ LA was appropriate for the fermentation of $\mathrm{LAB}$ in this product, consistent with the results of Lee et al. (2018). The reason for this toxic effect may be related to the structure of fatty acids and their isomers. With their double bonds, polyunsaturated fatty acids (PUFA), such as LA may join the cell membrane, damaging the lipid bilayer structure or diffusing the membrane, hence reducing its strength (Gorissen et al., 2015).

In this study, storage time did not significantly affect the CLA levels $(P>0.05)$ in kefir samples containing 0, 1 and 2\% LA. However, the CLA content in kefir decreased when $0.5 \%$ LA was used (Table 1). Some researchers revealed similar results, indicating that the CLA content was not affected by storage time (Rodríguez-Alcalá and Fontecha, 2007; Shantha et al., 1995). Although the CLA values differed slightly, this was not statistically significantly $(\mathrm{P}>0.05)$, except in samples containing $0.5 \%$ LA. Campbell et al. 
(2003) enriched skim milk with CLA, stored the sample for three weeks under refrigerated conditions, and found reduced CLA content, which they attributed microbial growth causing microbial lipase activity. Serafeimidou et al. (2013) demonstrated a decreased level of CLA in cow milk yoghurt but increased CLA levels in sheep milk yoghurt during 14 days of storage. In contrast, Shantha et al. (1995) found that storage time did not affect the CLA content. Domagała et al. (2009) observed decreased CLA levels in fermented cream during storage. In current study, the lowest CLA content was measured in the kefir sample containing $2 \%$ LA after 21 days of storage. This decrease can be related to microbial cultures as suggested by Sieber et al. (2004) or oxidative reactions in dairy products (Serafeimidou et al., 2013; Shantha et al., 1995), or even lipase activity (Campbell et al., 2003).

Table 1. The content of CLA in kefir $(\mathrm{mg} / \mathrm{g})$

\begin{tabular}{ccccc}
\hline \multirow{2}{*}{$\begin{array}{c}\text { Storage } \\
\text { time } \\
\text { (days) }\end{array}$} & $0 \%$ & $0.5 \%$ & $1 \%$ & $2 \%$ \\
\cline { 2 - 5 } & $0.77 \pm 0.039^{1 \mathrm{a}}$ & $0.83 \pm 0.031^{1 \mathrm{a}}$ & $0.73 \pm 0.076^{1 \mathrm{ab}}$ & $0.64 \pm 0.109^{1 \mathrm{~b}}$ \\
\hline 0 & $0.76 \pm 0.001^{1 \mathrm{a}}$ & $0.78 \pm 0.048^{12 \mathrm{a}}$ & $0.68 \pm 0.033^{1 \mathrm{ab}}$ & $0.64 \pm 0.110^{1 \mathrm{~b}}$ \\
2 & $0.79 \pm 0.017^{1 \mathrm{a}}$ & $0.79 \pm 0.050^{12 \mathrm{a}}$ & $0.73 \pm 0.098^{1 \mathrm{a}}$ & $0.68 \pm 0.106^{1 \mathrm{a}}$ \\
7 & $0.74 \pm 0.048^{1 \mathrm{ab}}$ & $0.78 \pm 0.046^{12 \mathrm{a}}$ & $0.71 \pm 0.114^{1 \mathrm{ab}}$ & $0.67 \pm 0.114^{1 \mathrm{~b}}$ \\
14 & $0.73 \pm 0.054^{1 \mathrm{a}}$ & $0.74 \pm 0.057^{2 \mathrm{a}}$ & $0.74 \pm 0.053^{1 \mathrm{a}}$ & $0.63 \pm 0.101^{1 \mathrm{a}}$ \\
\hline
\end{tabular}

a-b: means $( \pm$ SE, $\mathrm{n}=3)$ within same row with different superscripts differ significantly $(P<0.05)$

$1-2$ : means $( \pm \mathrm{SE}, \mathrm{n}=3)$ within same column with different superscripts differ significantly $(P<0.05)$

\section{CONCLUSION}

In the present study, the CLA level of kefir containing $0,0.5,1$ and $2 \%$ LA was evaluated during 21 days of storage at $4{ }^{\circ} \mathrm{C}$. The LA content above $0.5 \%$ reduced the CLA level of the samples due to the inhibitory effect of LA on LAB producing CLA. Nevertheless, storage time did not have a significant effect on the CLA amount of the kefirs samples containing 0,1 and $2 \%$ LA $(\mathrm{p}>0.05)$. On the other hand, the CLA level of samples with $0.5 \%$ LA was reduced during storage $(\mathrm{p}<0.05)$ due to oxidative reaction. The CLA level may also have been reduced by lipase activity, but this is considered to be less likely. Since LA could lead to the inhibition of the growth of microbial cultures, kefir containing $0.5 \%$ LA is a good source of CLA.

\section{ACKNOWLEDGEMENTS}

This project was financially supported by the Scientific Research Commission of Nigde Omer Halisdemir University (Project No:
FEB2015/39). The authors are grateful for the support.

\section{CONFLICT OF INTEREST}

Authors declare no conflict of interest.

\section{AUTHOR CONTRIBUTIONS}

Betül Oskaybas Emlek performed research. Betül Oskaybas Emlek and Ayşe Özbey analyzed data, designed research, and wrote the paper.

\section{REFERENCES}

Abd El-Salam, M. H., El-Shafei, K., Sharaf, O. M., Effat, B. A., Asem, F. M., and El-Aasar, M. (2010). Screening of some potentially probiotic lactic acid bacteria for their ability to synthesis conjugated linoleic acid. Int J Dairy Techn 63(1): 6269, https://doi.org/10.1111/j.14710307.2009.00541.x.

AOAC. (2005). Association of Official Analytical Chemists ( $A O A C)$. In: Horwitz W, Latimer GW (eds) Official methods of analysis,18th edition. AOAC International, Gathersburg. 
Barukčić, I., Gracin, L., Režek Jambrak, A., and Božanić, R. (2017). Comparison of chemical, rheological and sensory properties of kefir produced by kefir grains and commercial kefir starter. Mljekarstvo: casopis za unaprjedenje proizvodnje i prerade mlijeka, 67(3): 169-176, https://doi.org/ 10.15567/mljekarstvo.2017.0301.

Bhattacharya, A., Banu, J., Rahman, M., Causey, J., and Fernandes, G. (2006). Biological effects of conjugated linoleic acids in health and disease. $J$ Nutr Biochem, 17(12): 789-810, https://doi.org/10.1016/j.jnutbio.2006.02.009.

Campbell, W., Drake, M., and Larick, D. (2003). The Impact of Fortification with Conjugated Linoleic Acid (CLA) on the Quality of Fluid Milk. J Dairy Sci, 86(1): 43-51, https://doi.org/ 10.3168/jds.S0022-0302(03)73582-6.

Csapó, J., and Varga-Visi, É. (2015). Conjugated linoleic acid production in fermented foods. In Advances in Fermented Foods and Beverages, ed. by Wilhelm Holzapfel, Elsevier, pp. 75-105.

do Espírito Santo, A. P., Cartolano, N. S., Silva, T. F., Soares, F. A., Gioielli, L. A., Perego, P., et al. (2012). Fibers from fruit by-products enhance probiotic viability and fatty acid profile and increase CLA content in yoghurts. Int J Food Microbiol, 154(3): 135-144, https://doi.org/ 10.1016/j.ijfoodmicro.2011.12.025.

Domagała, J., Sady, M., Najgebauer-Lejko, D., Czernicka, M., and Wieteska, I. (2009). The content of conjugated linoleic acid (CLA) in cream fermented using different starter cultures. Biotechn in Animal Husbandry, 25(5-6-2): 745-751.

Farsad-Naeimi, A., Imani, S., R Arefhosseini, S., and Alizadeh, M. (2015). Effect of Safflower Oil on Concentration of Conjugated Linoleic Acid of Kefir Prepared by Low-fat Milk. Recent Patents on Food, Nutr \& Agri, 7(2), 128-133, DOI: 10.2174/2212798407666150831144122.

Gamba, R. R., Caro, C. A., Martínez, O. L., Moretti, A. F., Giannuzzi, L., De Antoni, G. L., et al. (2016). Antifungal effect of kefir fermented milk and shelf life improvement of corn arepas. International J Food Microbiol, 235: 85-92, https://doi.org/10.1016/j.ijfoodmicro.2016.06.0 38
Gao, J., Gu, F., Ruan, H., Chen, Q., He, J., and $\mathrm{He}, \mathrm{G}$. (2013). Induction of apoptosis of gastric cancer cells SGC7901 in vitro by a cell-free fraction of Tibetan kefir. Int Dairy Journal ,30(1): 14-18, https://doi.org/10.1016/j.idairyj. 2012.11.011.

Gaware, V., Kotade, K., Dolas, R., Dhamak, K., Somwnshis, S., Nikam, V., et al. (2011). The magic of kefir: a review. Pharmacology online, 1: 376386.

Gorissen, L., Leroy, F., De Vuyst, L., De Smet, S., and Raes, K. (2015). Bacterial production of conjugated linoleic and linolenic acid in foods: a technological challenge. Critical Reviews in Food Sci and Nutr, 55(11): 1561-1574, https://doi.org/ 10.1080/10408398.2012.706243.

Guzel-Seydim, Z., Seydim, A., Greene, A., and Taş, T. (2006). Determination of antimutagenic properties of acetone extracted fermented milks and changes in their total fatty acid profiles including conjugated linoleic acids. Int J of Dairy Techn., 59(3):209-215, https://doi.org/10.1111/ j.1471-0307.2006.00265.x.

Jenkins, J. K., and Courtney, P. D. (2003). Lactobacillus growth and membrane composition in the presence of linoleic or conjugated linoleic acid. Canadian J Microbiol, 49(1): 51-57, https://doi.org/10.1139/w03-003.

Jiang, J., Björck, L., and Fonden, R. (1998). Production of conjugated linoleic acid by dairy starter cultures. J Appl Microbiol, 85(1): 95-102, DOI: 10.1046/j.1365-2672.1998.00481.x.

Kepler, C. R., Hirons, K. P., McNeill, J., and Tove, S. (1966). Intermediates and products of the biohydrogenation of linoleic acid by Butyrivibrio fibrisolvens. J Biol Chem, 241(6): 1350-1354.

Kim, D.-H., Jeong, D., Kim, H., Kang, I.-B., Chon, J.-W., Song, K.-Y., et al. (2016). Antimicrobial activity of kefir against various food pathogens and spoilage bacteria. Korean $J$ Food Sci Animal Resources,36(6):787, doi: 10.5851/kosfa.2016.36.6.787.

Kim, Y., and Liu, R. (2002). Increase of conjugated linoleic acid content in milk by 
fermentation with lactic acid bacteria. J Food Sci, 67(5), 1731-1737, https://doi.org/10.1111/ j.1365-2621.2002.tb08714.x.

Lee, J. H., Kim, B., Hwang, C. E., Haque, M. A., Kim, S. C., Lee, C. S., et al. (2018). Changes in conjugated linoleic acid and isoflavone contents from fermented soymilks using Lactobacillus plantarum P1201 and screening for their digestive enzyme inhibition and antioxidant properties. $J$ of Funct Foods, 43:17-28, https://doi.org/10.1016/ j.jff.2018.01.022.

Li, H., Liu, Y., Bao, Y., Liu, X., and Zhang, H. (2012). Conjugated linoleic acid conversion by six Lactobacillus plantarum strains cultured in MRS broth supplemented with sunflower oil and soymilk. J Food Sci, 77(6): M330-M336, DOI: 10.1111/j.1750-3841.2012.02723.x.

Lin, T. Y. (2000). Conjugated linoleic acid concentration as affected by lactic cultures and additives. Food Chem, 69(1): 27-31, https://doi.org/10.1016/S0308-8146(99)002186.

Lin, T. Y., Lin, C.-W., and Lee, C.-H. (1999). Conjugated linoleic acid concentration as affected by lactic cultures and added linoleic acid. Food Chem, 67(1): 1-5, https://doi.org/10.1016/S03088146(99)00077-1.

Puniya, A. K., Chaitanya, S., Tyagi, A., De, S., and Singh, K. (2008). Conjugated linoleic acid producing potential of lactobacilli isolated from the rumen of cattle. J Indust Microbiol \& Biotechn, 35(11), 1223-1228, DOI: 10.1007/s10295-0080429-3.

Rodríguez-Alcalá, L. M., and Fontecha, J. (2007). Hot topic: Fatty acid and conjugated linoleic acid (CLA) isomer composition of commercial CLAfortified dairy products: Evaluation after processing and storage. J Dairy Sci, 90(5): 20832090, DOI: 10.3168/jds.2006-693.

Satir, G., and Guzel-Seydim, Z. B. (2016). How kefir fermentation can affect product composition? Small Ruminant Research, 134: 1-7, https://doi.org/10.1016/j.smallrumres.2015.10.0 22.
Sébedio, J.-L., Christie, W. W., and Adlof, R. (2003). "Advances in conjugated linoleic acid research", AOCS Publishing.

Sehat, N., Rickert, R., Mossoba, M. M., Kramer, J. K., Yurawecz, M. P., Roach, J. A., et al. (1999). Improved separation of conjugated fatty acid methyl esters by silver ion-high-performance liquid chromatography. Lipids, 34(4): 407-413.

Serafeimidou, A., Zlatanos, S., Kritikos, G., and Tourianis, A. (2013). Change of fatty acid profile, including conjugated linoleic acid (CLA) content, during refrigerated storage of yogurt made of cow and sheep milk. Journal of Food Composition and Analysis, 31(1): 24-30, https://doi.org/10.1016/ j.jfca.2013.02.011.

Shantha, N. C., Ram, L. N., O'leary, J., Hicks, C. L., and Decker, E. A. (1995). Conjugated linoleic acid concentrations in dairy products as affected by processing and storage. J Food Sci, 60(4): 695697, https://doi.org/10.1111/j.13652621.1995.tb06208.x.

Sieber, R., Collomb, M., Aeschlimann, A., Jelen, P., and Eyer, H. (2004). Impact of microbial cultures on conjugated linoleic acid in dairy products-a review. Int Dairy J, 14(1): 1-15, https://doi.org/10.1016/S0958-6946(03)001511.

Siurana, A., and Calsamiglia, S. (2016). A metaanalysis of feeding strategies to increase the content of conjugated linoleic acid (CLA) in dairy cattle milk and the impact on daily human consumption. Animal Feed Sci Techn, 217: 13-26, https://doi.org/10.1016/j.anifeedsci.2016.04.01 3 .

Van Nieuwenhove, C., Oliszewski, R., González, S., and Perez Chaia, A. (2007). Conjugated linoleic acid conversion by dairy bacteria cultured in MRS broth and buffalo mill. Letters in Appl Microbiol, 44(5): 467-474, https://doi.org/10.1111/j.1472765X.2007.02135.x.

Vargas, M., Cháfer, M., Albors, A., Chiralt, A., and González-Martínez, C. (2008). Physicochemical and sensory characteristics of yoghurt produced from mixtures of cows' and goats' milk. Int Dairy J, 18(12):1146-1152, https://doi.org/10.1016/j.idairyj.2008.06.007. 
Vieira, C., Álvares, T., Gomes, L., Torres, A., Paschoalin, V., and Conte-Junior, C. (2015). Kefir grains change fatty acid profile of milk during fermentation and storage. PloS one, 10(10): e0139910, journal.pone.0139910.

Whitlock, J. R., Heynen, A. J., Shuler, M. G., and Bear, M. F. (2006). Learning induces long-term potentiation in the hippocampus. Science, 313(5790): 1093-1097, DOI: 10.1126/ science.1128134.

Xu, S., Boylston, T. D., and Glatz, B. A. (2004). Effect of lipid source on probiotic bacteria and conjugated linoleic acid formation in milk model systems. J Am Oil Chem' Society, 81(6): 589-595, https://doi.org/10.1007/s11746-006-0946-z.

Zelovitis, I., Vlachou, A.-M., Pappa, E. C., and Kondyli, E. (2016). Manufacture of A "Functional" Fermented Milk Product with the Addition of an Alcoholic Plant Origin Extract. Current Research in Nutr and Food Sci, 4 (Special Issue Nutrition in Conference October 2016), 97104, http://dx.doi.org/10.12944/ CRNFSJ.4.Special-Issue-October.13. 